\title{
Geochemical and mineral compositions of Tajikistan loess and their provenance implication
}

\author{
Yougui Song ${ }^{1,2}$, Yue Li ${ }^{1}$, Xiuling Chen ${ }^{3}$, XiUlan \\ ZONG $^{1}$, YUNUS MAMADJANOV ${ }^{4}$ \\ ${ }^{1}$ State Key Laboratory of Loess and Quaternary Geology, \\ Institute of Earth Environment, Chinese Academy of \\ Sciences, Xi'an 710061, China; \\ ${ }^{2}$ CAS Center for Excellence in Quaternary Science and \\ Global Change, Xi'an 710061, China; \\ ${ }^{3}$ College of Geographical Sciences, Fujian Normal \\ University, Fuzhou 350007, China \\ ${ }^{4}$ Research Center for Ecology and Environment of Central \\ Asia (Dushanbe), Dushanbe 734063, Tajikistan
}

Geochemical and mineral compositions of aolian loess are important properties to discriminate dust provenance. Tajikistan (TJ) loess in Central Asia provides an insight into the dust source variation and climate change in the midlatitude Northern Hemisphere. However, dust provenance is still hotly debated. Here, we employ XRF, ICP-MS and XRD methods to investigate geochemical and mineral compositions and provenance of loess in Vakhsh valley, SW Tajikistan. The results indicated that 1) major element content is $\mathrm{SiO}_{2}>$ $\mathrm{Al}_{2} \mathrm{O}_{3}>\mathrm{CaO}>\mathrm{Fe}_{2} \mathrm{O}_{3}>\mathrm{MgO}>\mathrm{K}_{2} \mathrm{O}>\mathrm{Na}_{2} \mathrm{O}>\mathrm{TiO}_{2}>\mathrm{P}_{2} \mathrm{O}_{5}>$ $\mathrm{MnO} ; 2$ ) contents of $\mathrm{SiO}_{2}, \mathrm{Al}_{2} \mathrm{O}_{3}, \mathrm{Fe}_{2} \mathrm{O}_{3}, \mathrm{TiO}_{2}$ and $\mathrm{MnO}$ in paleosols are higher than in loess, whereas $\mathrm{CaO}, \mathrm{MgO}$ and $\mathrm{P}_{2} \mathrm{O}_{5}$ contents are lower in paleosols; 3) trace elements distribution patterns of $\mathrm{TJ}$ loess and paleosol samples are similar, though their contents in paleosol are higher than in loess except for Sr. Compared with UCC, all trace elements except $\mathrm{Ba}, \mathrm{Sr}$ and $\mathrm{Zr}$ in paleosol show enrichment, but in loess, some trace elements (e.g., $\mathrm{Ba}, \mathrm{Co}, \mathrm{Ni}$ and $\mathrm{Zr}$ ) show depletion; 4) XRD reveals that at least ten minerals are identified, major mineral in TJ loess is quartz, followed by feldspar and calcite, there are few chlorite, micas, dolomite, amphibole, etc, and occasionally heavy minerals. Loess from TJ, Chinese Loess Plateau (CLP) and the Ili Basin have the similar mineralogical components, but the contents of quartz and calcite in TJ loess are lower, the content of amphibole is somewhere in between CLP loess and Ili loess, reflecting the weakly weathering environment with short transportation. Geochemical and mineral compositions of TJ loess and paleosols have the same proximal provenance. TJ loess materials originated from the quartzose sedimentary was mainly transported by near-surface northerly or northwesterly winds, and Kara Kum desert in the west presumably has played a minor role in providing material for the TJ loess. 